This is an electronic reprint of the original article. This reprint may differ from the original in pagination and typographic detail.

Author(s): Pehkonen, Jaakko; Hynninen, Sanna-Mari; Ojala, Jari

Title: Technological change and wage premiums: historical evidence from linked employeremployee data

Year: $\quad 2013$

Version:

Please cite the original version:

Pehkonen, J., Hynninen, S.-M., \& Ojala, J. (2013). Technological change and wage premiums: historical evidence from linked employer-employee data. Labour Economics, 24(10), 1-11. https://doi.org/10.1016/j.labeco.2013.05.006

All material supplied via JYX is protected by copyright and other intellectual property rights, and duplication or sale of all or part of any of the repository collections is not permitted, except that material may be duplicated by you for your research use or educational purposes in electronic or print form. You must obtain permission for any other use. Electronic or print copies may not be offered, whether for sale or otherwise to anyone who is not an authorised user. 


\title{
Technological Change and Wage Premiums: Historical Evidence from Linked Employer-Employee Data
}

\author{
Sanna-Mari Hynninen*, Jari Ojala**, and Jaakko Pehkonen***
}

\begin{abstract}
This study analyses the impacts of a technological change (the steam engine) on wage premiums. Using historical employer-employee panel data, we found that steam technology had both new skill-demanding and skill-replacing aspects. The former manifested itself as an increase in the demand for high-skilled engineers, the latter in a decline in the demand for intermediate-skilled, able-bodied seamen and an increase in the demand for unskilled engine room operators. Our panel data analysis, which controls for unobserved heterogeneity, implies that highskilled labourers in abstract tasks and unskilled labourers in manual tasks improved their wage positions relative to intermediate-skilled labourers in routine tasks. These findings are compatible with the hypothesis of technologybased polarisation.
\end{abstract}

Keywords: wage, premium, skill, task, technological change, polarisation JEL classification: J31

* Central Finland Chamber of Commerce and School of Business and Economics, University of Jyväskylä, Finland, email: sanna-mari.hynninen(at)chamber.fi

**Department of History and Ethnology, University of Jyväskylä, Finland, email: jari.ojala(at)jyu.fi.

***School of Business and Economics, University of Jyväskylä, Finland, email: jaakko.k.pehkonen(at)jyu.fi. Corresponding author.

We are indebted to Miikka Rokkanen and Sampo Pehkonen for their research assistance. We thank participants in the $21^{\text {st }}$ EALE Conference in Tallinn, the $5^{\text {th }}$ IMEHA Congress in Greenwich, David Autor, and two anonymous referees for useful comments on an earlier draft of this paper. The financial support of the Yrjö Jahnsson Foundation (6406) and the Academy of Finland (251071) is gratefully acknowledged. 


\section{Introduction}

The observed rise in overall wage inequality, particularly in the US and UK labour markets, has generally been accounted for by skill-biased technological change (SBTC). According to the SBTC hypothesis, technological advances raise the relative demand for skilled labour, and thus skilled labourers' wages, in every task. The majority of studies have used empirical data from the last two or three decades, which has been a rational approach as the information technology (ICT) revolution ${ }^{1}$ of the 1980s provided an interesting basis for research on the impact of new technology on the labour market. Bound and Johnson (1992), Katz and Murphy (1992), Berman et al. (1998), Juhn (1999) and Acemoglu (2002) have made well-known contributions in the area of SBTC. Katz and Autor (1999) offer an excellent review of the literature of the 1980s and 1990s, whereas Card and DiNardo (2002) and Lemieux (2006) provide a critical view of the helpfulness of the SBTC hypothesis in understanding shifts in the wage structure observed over recent decades.

The most recent literature has opted for a new concept: technology-based polarisation. According to this view, there has been a shift in employment towards both the highestskilled and lowest-skilled occupations with declining employment in the intermediateskilled occupations. This view, also termed the "routinization hypothesis" (Autor et al. 2003), suggests that technological advances lead to an increase in the demand for jobs with non-routine tasks at the expense of jobs with routine tasks. Non-routine tasks can be either abstract jobs, such as managerial and professional positions, at the top end of the wage distribution, or manual jobs, such as services, at the bottom end of the wage distribution. Routine tasks, such as office jobs, are, in turn, concentrated in the middle of the wage distribution. Autor et al. (2006, 2008), Goos and Manning (2007), Goos et al. (2009), Van Reenen (2011) and Autor and Dorn (2012) are the most recent empirical contributors to this literature.

\footnotetext{
${ }^{1}$ By ICT revolution, we refer to adoption of information and computer technology, such as the use of computer-aided manufacturing, digitisation, personal computers and related technologies, including the Internet.
} 
In this study, we contribute to the empirical research on the impact of technological change on the labour market by analysing historical data from an industry (shipping) that faced a significant technological change (the steam engine) in the mid-1800s. ${ }^{2}$ Economic historians such as North (1958, 1968), Harley (1971, 1988), Fischer (1979), and Unger (2011) have all stressed the productivity growth caused by this technological change. Harley (1988) and North (1968), in particular, emphasise the technological change from sails to steam and from wood to iron and steel as the major source of this productivity growth and, thus, for the declining freight rates and, consequently, the increase in international trade.

The change in the quality and labour costs of mariners has attracted less attention, although the composition of crews changed as a consequence of the new technology. Chin et al. (2006) have noted that a premium was paid for the new groups of workers and to the seamen that had the same occupations on the steamers that they previously had on sailing ships. "Old" sailing professionals, such as able-bodied or ordinary seamen, could also be hired to work on steamers. New professions were also created, as there was a sudden need for high-skilled engineers and for unskilled workers, such as engine room operators, trimmers to carry coal and firemen to shovel the coal into the boilers. Furthermore, as noted by Kaukiainen (1991), with the advent of the steamship came the introduction of the passenger vessel, which led to the creation of more new jobs, such as stewards and waitresses.

This research uses Swedish merchant tonnage to study how the introduction of steam to merchant shipping affected the wages of the seamen. In Sweden, the first trial of a steam-powered vessel was conducted in 1816, but it would not be until 1899 that steam tonnage would surpass sailing tonnage. ${ }^{3}$ Sweden's share of the world merchant fleet

\footnotetext{
${ }^{2}$ Although steam technology was first introduced in shipping around 1803, it was not until the late nineteenth century that the technology became efficient enough in longdistance trade to supplant sails, as noted in pivotal studies by Graham (1956) and Harley (1971).

${ }^{3}$ See Fritz (1980). The same was true for Denmark and Norway, which experienced the change from sails to steam around the-mid 1890s (Hornby and Nilsson 1980; Gjolberg 1980), while Finland did not make this transition until the first years of the $1920 \mathrm{~s}$ (Kaukiainen 1991).
} 
was between 2.5 and 3.0 per cent during the latter part of the nineteenth century. As noted by Fritz (1980), in 1900, Sweden's share of the global merchant fleet was higher in sailing ships (3.5 per cent) than in steam vessels (1.5 per cent). The Swedish tonnage grew from the 1850 s through 1870 s, mainly through investments in new sailing vessels that peaked in the 1880s. From the early 1880s, the growth in Swedish tonnage was achieved through investments in steam vessels. While in 1880, the share of steam vessels was only 15 per cent of total tonnage, by 1907 steam tonnage was twice as high as sailing tonnage. Thus, Sweden serves as a good case for the study of this technological change and its effect on the demand for skilled seamen.

The data used in this paper are compiled from the recruitment records of seamen's houses. ${ }^{4}$ This Arkion database of Swedish merchant mariners consists of approximately 650,000 enrolments by seamen in various Swedish port towns. Our analysis utilises a sample from six towns spanning from the 1860s to the early 1910s. The data contain information on individual wages, job attributes and workplace characteristics. In particular, it provides information on mariners' occupations and includes a reference to job tasks. The dataset is outstanding and informative in two particular ways.

First, the technological innovation of the steam engine resulted in a major change in the maritime industry, that is, a gradual replacement of sail-only vessels by steam-powered vessels. The new steam technology not only changed the capital intensity of the industry but also created new occupations with new job tasks, including engineers and engine room operators, such as trimmers and firemen. The former group represents a highskilled occupation focused on abstract tasks. The latter is a good example of an unskilled occupation focused on manual tasks. The transition period from sail to steam that lasted several decades provides an interesting and well-structured case to examine how the wages of old and new occupations evolve along with the adoption of a new technology. Analyses that exploit high-quality historical data to study wage structures are few, although they could offer perspectives relevant to the recent discussion on the

\footnotetext{
${ }^{4}$ The data were compiled by Swedish National Archives in the late 1990s and published as a CD-Rom under the title "Arkion". For further information, see: http://www.arkion.ra.se/.
} 
impacts of technological change on the labour market based on data from the contemporary ICT revolution. ${ }^{5}$

Second, the dataset provides critical information for assessing the impact of a new technology on the wage structure. Two features of the data are particularly worth emphasising. First, we can relate occupations to job tasks, which, in turn, can be labelled abstract, routine or manual. This allows us to shed light on the emerging literature on technology-based polarisation that predicts an increase in the demand for skilled and unskilled labour in abstract and manual jobs at the expense of moderately skilled routine jobs. Second, panel data that draw a precise relationship between the seaman, the vessel and the prevailing technology, provide controls for observed and unobserved heterogeneity in the econometric analysis of wages. The ability to identify 1,027 seamen who moved from a sail-only vessel to a steam-powered vessel or vice versa (adopters of the new technology) provides 3,271 observations to estimate the wage impact of steam technology on different occupational groups during the period when the new technology was adopted.

The structure of the paper is as follows. Section II presents the theoretical basis of the study by discussing the role of production technology in the demand for skills in the context of the maritime industry. We combine Goldin and Katz's (1998) model of technology changes and demand for skills with that of Autor et al. (2003), who assume that technological change treats different job tasks non-monotonically, particularly by decreasing the demand for routine jobs. By describing the data in Section III, we shed preliminary light on the hypotheses of skill-biased technological change and technology-based polarisation in a historical context. The section describes changes that occurred in the maritime industry during the sample period, including the transition in the prevailing technology from sail-only vessels to steam vessels, changes in the occupational structure of the crews and basic statistics on wages by occupation and wage distributions by technologies and over time. The section also contributes to the literature by providing detailed information on workers who switch occupations due to

\footnotetext{
${ }^{5}$ Rare examples using historical data include Atack et al. (2004), Chin et al. (2006) and Goldin and Katz (2008).
} 
technology (technology switchers): from which occupations and percentiles in the sail wage distribution the switchers to steam come and which occupations they obtained on steam ships.

In Section IV, we employ a regression framework and panel data methods to test the theoretical model derived in Section II. The section consists of two parts. First, we analyse the direct wage effect of steam technology. This is performed by estimating the steam technology premiums for the occupations that existed under both technologies. In this analysis, we utilise data on those mariners who switched between the two technologies during their careers. To separate the impact of technological change from the impact of a simultaneous occupational change, we examine only those switches where the last occupation on a sail (steam)-driven ship and the first occupation on a steam (sail) vessel after the transition were the same. Second, we examine the relative wage effects of steam technology. Specifically, how new, emerging occupations change the relative wage position of the old occupations and how occupational premiums evolve over the adoption phase are our particular interest. Finally, Section V concludes the paper. 


\section{The polarising effect of the steam engine on the wage structure: a theoretical framework}

Goldin and Katz (1998) present a theoretical framework for the wage effects of a technological change where the production process is modelled in two stages. In the first stage of production, skilled labour and raw capital are used to produce workable capital. In this stage, skilled labour and raw capital strongly complement each other. In the second stage of production, the workable capital produced in the first stage and the unskilled labour are employed as inputs in a Cobb-Douglas production function for producing the final output. Technological change plays a role in the first stage of the process by increasing the capital intensity of production and the productivity of skilled labour.

Autor et al. (2003) unravel the effect of the new technology on different job tasks, which then affects the skills required for labour. They introduce a model where technological change is assumed to treat different job tasks non-monotonically by decreasing the demand for routine job tasks, which are typically located in the middle of the skill distribution. The demand for non-routine tasks (abstract and manual) that are located at the top and the bottom of the skill distribution, respectively, increases. An increase in the demand for unskilled labour in the manual tasks and high-skilled labour in the abstract tasks combined with a decrease in the demand for moderately skilled labour in the routine tasks weakens the relative position of those in the middle of the skill distribution and polarises the labour market.

We apply Goldin and Katz combined with Autor et al. to the context of the effect of the advent of the steam engine on vessels. We assume that the production process for both sail and steam vessels consists of two parts: the production of workable machines $K^{*}$ at the first stage and the production of the final product $Q$ at the second stage. In the maritime industry, $Q$ consists of the miles of safe and timely passage over the ocean.

There are four factors of production. Three of the factors are labour inputs, and the fourth is the raw capital: steam engines $(K)$. The labour inputs are defined by the type of tasks with which they are associated: manual task labour $\left(L_{m}\right)$, routine task labour ( 
$\left.L_{r}\right)$ and abstract task labour $\left(L_{a}\right)$. The abstract tasks on vessels are performed by highskilled labour such as mates and engineers, and the manual tasks are performed by unskilled labour such as ordinary seamen and engine room operators.

We consider five occupations performing different tasks. These are mates (M), ablebodied seamen $(\mathrm{AB})$, and ordinary seamen (OS). Two new occupations created by the new technology that were required on steam-operated vessels, engineers (ENG) and engine room operators (EOR), are also identifiable. Our knowledge of the skills required for the different tasks in the nineteenth-century shipping industry suggests that these occupations can be classified into three skill/task groups. These are high-skilled and high-wage mates and engineers (engaging in abstract tasks, $L_{a}$ ), intermediateskilled and middle-wage able-bodied seamen (completing routine tasks, $L_{r}$ ) and unskilled and low-wage ordinary seamen and engine room operators (fulfilling manual tasks, $\left.L_{m}\right)$.

According to Chin et al. (2006), all vessels had one master who was assisted by one or more mates. The duties of mates include managerial and supervisory tasks with nonengine room workers, responsibility for the cargo, maintaining the logbook, navigational measurements and commanding the round-the-clock watches. Most mates attained their high status by spending years on vessels as able-bodied seamen and passed examinations administered by the government. ABs were experienced seamen that completed routine tasks, such as handling the ropes to achieve the positions desired of the masts, spars and sails on sailing vessels. The skills of the able-bodied seamen were also in demand on steam vessels that continued to be equipped with sails until the beginning of $20^{\text {th }}$ century. This formerly key position in the crew was however lost and the new position was more akin to working as backup persons in instances of technical problems with the steam engine. OSs were sailors with a rather limited amount of experience, and thus, were primarily used to carry out manual tasks, such as the simplest aspects of handling ropes to make the ship sail or the simplest aspects related to the operations of the steam engine. ENGs were the key labourers on steam vessels. They collaborated with EORs in the engine room isolated from the rest of the crew. Technical college with certifying exams and apprenticeships preceded the promotion to 
the position of engineer. The tasks included tending the machinery and ensuring that it was operating properly, undertaking repairs, responsibility for the engine when arriving in or leaving port and the supervision of the firing of the boilers. EORs worked under the management of the ENGs. The majority of the EORs were the trimmers carrying the coal from the storage areas to the boiler areas and the firemen shovelling coal into the boilers to generate steam.

The first stage of production on vessels, the production of workable machines $K^{*}$, takes the following Cobb-Douglas form:

$$
K^{*}=\left(L_{r}+K\right)^{1-\beta} L_{a}^{\beta}, \beta \in(0,1)
$$

All inputs are measured in efficiency units. The steam engine $K$ is supplied perfectly elastically at the market price $p$ per efficiency unit. The market price $p$ exogenously declines in the adaptation period of the steam engine and hence works as an exogenous driving force in the model. The elasticity of substitution between abstract labour and total routine task input is one, while routine task labour and steam engine labour are perfect substitutes, as indicated by the production function (1). By implication, $K$ is a relative complement to abstract labour, while it is a relative substitute for routine labour. Due to the q-complementary, the marginal productivity of abstract labour increases with the routine task inputs.

In the second stage of production, manual task labour $L_{m}$ and usable capital $K^{*}$ are used to derive at the final product $Q$ (miles of safe and timely passage over the ocean):

$$
Q=K^{1-\alpha} L_{m}^{\alpha}, \alpha \in(0,1)
$$

Consistent with Autor et al. (2003), we assume that educational supply is exogenous and the workers capable of performing abstract tasks, mates and engineers, are endowed with one efficiency unit of abstract skill, which they supply inelastically to abstract tasks on vessels. Furthermore, we assume that the able-bodied seamen do not possess abstract skills and each is instead endowed with one efficiency unit of manual skill and $\eta_{i}$ efficiency units of routine skill, where $\eta$ is distributed continuously on the unit 
interval with a positive mass at all points $\eta \in[0,1]$. OSs and EORs are only capable of performing manual tasks.

Let $w_{m}$ and $w_{r}$ denote the wages paid for manual and routine work, respectively. Each AB $i$ chooses to supply one efficiency unit of labour to manual tasks or $\eta_{i}$ efficiency units of labour to routine tasks. The decision is based on the relative wage of each type of work. If $\eta_{i}<w_{m} / w_{r}$, the $\mathrm{AB}$ selects manual tasks and selects routine tasks otherwise. When the exogenous price of the steam engine $(p)$ (and thereby $w_{r}$ ) falls, those ABs who are endowed with relatively low $\eta_{i}$ self-select away from routine to manual tasks on vessels. Due to the q-complementarity of routine and manual tasks on vessels, the steam engine raises the marginal productivity of manual task labour input, resulting in an increase in the wages of manual labour. A shift of additional labour from routine to manual tasks, however, works against the beneficial effect of steam technology on manual wages. Thus, it is possible that both $w_{m}$ and $w_{r}$ could fall with a decrease in $p$, despite that the manual task wage relative to the routine task wage $w_{m} / w_{r}$ unambiguously increases.

The effect of steam technology on high-skilled wages follows the SBTC hypothesis because, due to q-complementarity, workers in abstract tasks also benefit from an increase in routine task input. Unlike manual tasks, however, there is no additional labour supply response from the intermediate-skilled labour force because the ABs are not capable of performing the tasks of mates or engineers. As a consequence, the steam engine unambiguously increases $w_{a}$ both absolutely and relative to $w_{r}$ and $w_{m}$. To summarise, the model indicates that the adoption of the steam engine fundamentally weakened the relative position of the intermediate-skilled routine task labour force, ABs, while benefiting the high-skilled abstract task labour force, Ms, and potentially also benefiting the low-skilled manual task labour, OSs. In the following sections, we use a unique dataset to test the empirical relevance of this hypothesis. In addition, we consider the position of the new abstract task labour input of ENGs and manual task labour input of EORs. 


\section{Changes in technology, occupational compositions, wages and technology switchers in the maritime industry}

\section{Data}

In this study, we exploit seamen's house documents collected from six major port towns in Sweden. These are, in alphabetical order, Gävle, Härnösand, Hudiksvall, Karlskrona, Söderhamn, and Visby. The seamen's house (sjömanshus) was a public institution introduced in Sweden in the mid-18th century. It was established to collect data on the number of sailors available to the military. In practice, the houses played an important role in the labour market, and every seaman going abroad would have been enrolled at a seamen's house. When a ship returned, documents were completed with its date of arrival and information about the voyage, including possible deaths, illnesses, and desertions. $^{6}$

Our basic sample consists of more than 32,000 individuals employed on over 1,500 vessels during the period between 1869 and 1914. The data comprise one of the earliest examples of employer-employee information. ${ }^{7}$ They contain detailed individual-level information, including the name, date and place of birth, age, marital status, salary, occupation on board and date of hire for every seaman listed. The name, tonnage, type, and likely destination of the vessel on which each sailor worked are also documented. A major advantage of the data is that they documented individual wages and occupations and that information is linked to the characteristics of the voyage and vessel, including its technological status.

For the purpose of the empirical analysis, we identify three major occupational groups under both technologies with a significant number of observations in each year. These

\footnotetext{
${ }^{6}$ See Ojala and Pehkonen (2009) for a detailed description of the data.

${ }^{7}$ The data examined in Chin et al. (2006), which were taken from the Maritime History Archive, are of a similar type. Their analysis focusing on the merchant marines of ten major Atlantic Canadian ports covers the period 1891-1912. For the use of establishment-level data in a contemporary setting, see Dunne et al. (1997). Dunne et al. (2004) and Machin and Van Reenen (1998) present excellent examples of an industry panel.
} 
are mates, able-bodied seamen, and ordinary seamen. Two new occupations created by the new technology that were required on steam-operated vessels, engineers and engine room operators, are also identifiable. We classify the occupations in three task groups that required different skills. These are high-skilled and high-wage mates and engineers (engaging in abstract tasks, $L_{a}$ ) intermediate-skilled and middle-wage able-bodied seamen (performing routine tasks, $L_{r}$ ) and unskilled and low-wage ordinary seamen and engine room operators (fulfilling manual tasks, $\left.L_{m}\right){ }^{8}$

The hypothesis of skill-biased technological change posits an increase in the demand for high-skilled labour relative to unskilled labour. Technology-based polarisation, in turn, implies an increase in the demand for abstract and manual tasks and a decrease in the demand for routine tasks. We will shed preliminary light on these hypotheses by reporting statistics on the occupational composition of the crew and wages by occupation over time and by technology (figures 2 and 3 and Table 1), the average wage growth by deciles in the earliest and latest years of the adaptation period (figure 4), seamen's transitions between occupations and technologies (tables 2 and 3), and the average wages of technology switchers by occupation (table 4). We begin, however, by illustrating the pace of technological transition in the maritime industry during the years from 1869 to 1914 (figure 1).

\section{Occupational compositions and wage bill shares on vessels}

Figure 1 depicts the evolution of steam technology as the percentage share of steam vessels among all vessels over the period of study. Both the weighted and unweighted measures are plotted. The former measure weights the vessels by their capacity (tonnes). The figure reveals that the transition from the prevailing technology (sail) to the new technology (steam) was a long-lasting process. The first steam vessels flying the

\footnotetext{
${ }^{8}$ Captains are excluded from the analysis because their wage compensations typically include unidentifiable profit shares for which we have no records. Similarly, we omit less frequent occupations, such as cooks, stewards and deck boys, and we do not analyse those new tasks that surfaced after the introduction of steam-powered passenger vessels.
} 
Swedish flag in this sample began operation in 1869, but it was more than 20 years before steam vessels achieved a 20 per cent share of total capacity. The pace of adoption was rapid from 1890 to 1910, and by 1914, steam vessels accounted for approximately 86 per cent of total capacity. This is consistent with the previous study by Fritz (1980). Between the periods 1869-90 and 1890-1910, the number of seamen employed by sail driven vessels was halved from 19,742 to 10,025. This decline is paired with a proportionally equivalent increase in the number of seamen employed by steam driven vessels, from 2,958 to 5,553. The decline in the absolute number of seamen suggests a considerable decrease in the demand for labour in the industry. However, this observation cannot be generalised to the entire maritime industry because our data consist of a sample of six port towns.

Figure 2 demonstrates that the decline in the share of ordinary seamen in the maritime industry was continuous over the period, falling from 43 per cent in 1869 to 29 per cent in 1914. The share of able-bodied seamen declined from 21 per cent to 13 per cent during the same period. The share of mates also declined, from 18 per cent to 14 per cent. These declines coincided with an increase in the shares of engine room operators and engineers. In short, the steam period from 1869 onward is characterised by the emergence of new occupations, high-skilled (engineers) and unskilled (engine room operatives), and declines of approximately the same proportions in other occupations. In absolute terms, the changes were considerable.

Between the periods 1861-90 and 1891-1910, the ordinary seamen suffered the greatest absolute decline, their numbers falling by more than 5,000 men employed in sailing over the periods. The able-bodied seamen, in turn, experienced the most severe proportional decline in sailing, their numbers falling by more than 2,000 men, which implies a 60 per cent decline over the periods. For mates, the numbers were slightly better. Their absolute numbers declined by 1,400 men, equating to a 40 per cent decline. The corresponding increases on steamboats were highest for engine room operators and engineers. For the former group, the increase was 150 per cent (1,002 men) and 94 per cent (240 men) for the latter over the periods. Additionally, the older occupations increased their numbers on steamboats. In absolute terms, the total growth was 
approximately 1,300 seamen. Proportionally, the mates performed the best and, as before, the able-bodied seamen performed the worst.

[Figures 1 and 2 about here]

The technological change related to steam power had both a new-skill-demanding aspect, manifested as an increase in the demand for engineers, and a skill-replacing aspect, resulting in a decline in the demand for able-bodied and ordinary seamen and an increase in engine room operators. This summary is consistent with the results in Table 1, which report the occupational composition of the crew and wage bill shares of the average sailing voyage and average steam voyage over the period 1869 to 1914 . The differences across the types of the vessels are substantial. The shares of mates and ablebodied seamen in the crew are 7 percentage points lower on steam vessels than on sailing vessels, down from 35 per cent to 28 per cent. The difference in the proportion of ordinary mariners is even more marked, down from 42 per cent of the crew on sailing vessels to 24 per cent on steam vessels. These changes are offset by increases in the shares of engineers (11 per cent) and engine room operators (27 per cent). Wage bill shares confirm these differences across technologies. The wage bill shares of mates (28 per cent), able-bodied seamen (21 per cent) and ordinary seamen ( 29 per cent) on sailing vessels fell to between 12.5 per cent and 15.4 per cent of the total wage bill on a typical steam vessel. ${ }^{9}$

[Table 1 about here]

Wage inequality over time

Figure 3 indicates that differentials in mean wages across occupations were notable. In the case of sail-only occupations, they were also relatively stable over the sample, as mates consistently earned (on average) more than able-bodied seamen and able-bodied seamen always earned more than ordinary seamen. The mean wages of engineers, the

\footnotetext{
${ }^{9}$ Within old occupations the ratio of wage bill share to employment share changes when moving from sail to steam technology: it increases for mates, declines for able bodied seamen and remains constant for ordinary seamen.
} 
high-skilled group on steam vessels, were higher than those of mates, a dominant group of high-skilled labour on sailing vessels. Engine room operators on steam vessels performed manual tasks and earned more than ordinary seamen on sailing vessels. In fact, the average wages of engine room operators matched those of moderately skilled, able-bodied seamen engaged in routine tasks. As the study by Chin et al. (2006) notes, premiums from working on steam vessels may include a compensating differential for the unpleasant work environment and for skills gained from training. The former explanation applies to engine room operators, who often worked under poor conditions below decks. The latter better suits the engineers, who also had work opportunities on land.

Our data show that mean wages were higher on steam-operated vessels, as the uncontrolled steam premium varied from 30 per cent to 47 per cent over the period from 1869 to 1914. If engineers and engine room operators are excluded from the sample, the mean wage premium on steam-operated vessels decreases, on average, to 13 - 30 per cent over the same period. This implies that the new-skill-demanding aspect of technological change clearly accounts for the observed increase in the mean wage. This is consistent with the findings of Chin et al. (2006) for the Canadian merchant shipping industry, as they observed that the steam premium would decrease from 43 per cent to 26 per cent if engineers were excluded from the sample. Another obvious explanation for the increase in the mean wage is related to the increased productivity generated by larger ships. Capacity, measured by gross tonnes, increased during the period, on average, by 1 per cent per annum, and, in addition, it was considerably higher for steampowered vessels than for sail-only vessels. ${ }^{10}$ Although, as noted by Kaukiainen (1991), this productivity increase was not obvious in the case of early steamers, as larger bunkers and coal cargoes reduced the cargo carrying capacity, the men per tonne being approximately the same for the late nineteenth-century steamers as it was for the samesized sailing vessels.

${ }^{10}$ The subsequent empirical analysis indicates that a 10 per cent increase in vessel capacity increases wages by approximately 0.2 per cent. Mitchell (2005) provides a model that accounts for interactions between plant size, capital and the skill premium. 
Regarding wage inequality, the data indicate that variations over the decades are modest within technologies but substantial across technologies. The average coefficient of variation over the period of study is 0.43 for the sail and 0.56 for the steam technology, that is, 30 per cent higher for steam. The increase in overall wage inequality in the maritime industry can be associated with the emergence of a new technology that resulted in new occupations. If we exclude engineers from the steam sample, the average value of the coefficient of variation for steam technology declines from 0.56 to 0.47. This can be viewed as indirect support for the SBTC hypothesis.

To illustrate the possible wage polarisation in the maritime industry, we report the average wage growth by deciles from the slow growth period of the adaptation of the steam engine, 1869 to 1890 , and from the rapid growth period, 1890 to 1914. Three notes emerge from Figure 4. First, the average wage growth in all deciles is higher in the latter period than in the former. This indicates a positive impact of the new steam technology on average wages. As previously noted, the impact is also likely to reflect a trend towards bigger vessels. Second, the wage evolution in the first period indicates, to some extent, a positive correlation with wages and wage growth; in particular, the highest wage growth for the highest decile is consistent with the SBTC hypothesis. Third, although no perfect U-shaped distribution is found, the wage growth in the second period reveals signs of polarisation, with the fastest wage growth in the lowest and highest deciles.

[Figures 3 and 4 about here]

\section{Occupations and wages of technology switchers}

Tables 2 and 3 provide a picture on seamen's job-moves within and between technologies. The tables tabulate transitions as percentages, whereas absolute numbers of job-moves are provided in the footnotes below the tables. The results are, first, in line with previous findings on occupational mobility within an industry, i.e., the probability of remaining in the same occupation is always higher than switching. This feature is more apparent under the steam technology where these estimates vary from 0.78 (ordinary seamen) to 0.90 (mates). On the sail vessels, the estimates are between 0.60 and 0.69 . Second, a number of mariners obtain a better position over time: 817 ordinary 
seamen and 731 able-bodied seamen serve as mates under the sail technology during their later career. Similarly, over ten per cent of all engine room operators serve as engineers (51 cases). There are also job-moves from better paid occupations to occupations that pay less. Such cases are more evident in sail vessels.

Third, technology switches occur in both directions and do not typically imply an occupational change. In most cases, seamen end up in the same occupation on steamships that they had on sailing vessels, and vice versa. This relationship is particularly strong for mates and able-bodied seamen switching from sail to steam; the share of such job-moves where the initial occupation is retained varies between 56-70 per cent. Ordinary seamen are an exception, where technology changes occur simultaneously with a change in occupation. The share of such switches is 63 per cent when the job-move is from sail to steam. In these cases, the typical new occupation is an engine room operator, i.e., a trimmer or fireman. Fourth, mariners in the old occupations on sailing vessels are unlikely to move into the new occupations on steamships. Less than 10 per cent of all changes from the positions of mate, able-bodied seamen or ordinary seamen are to a position of an engineer or engine room operator. This suggests that, given the growth in the share of the steam technology, most of the seamen in the new occupations were entrants to the maritime industry. The finding that engineers and engine room operators are unlikely to switch into the old occupations on the sailing vessels supports this view. Furthermore, the results indicate that there is segregation between the old and new occupations. This, in turn, provides one possible source for long-lasting wage premiums between the occupations.

Table 4 compares the wages of technology switchers by occupation, both from sail to steam and steam to sail, to the average wages under the technology from which the switcher initially came. For the sake of space, we only examine two subsamples. ${ }^{11}$ The numbers indicate that the wage differentials and wage distributions between the jobswitchers and the overall sample are modest. However, two remarks are in order here. First, the wages of those transitioning from sail to steam are consistently above the average wages of their occupation. In the case of job-moves from steam to sail, the

\footnotetext{
${ }^{11}$ Switchers are distributed relatively evenly over time, and hence a modest rise in wages does not obscure the interpretation.
} 
pattern is diverse. The basic picture is that switchers from steamboats come from lower wage positions, at least when compared to switchers from sailing vessels. Second, wage differentials across occupations increase under the steam technology, and these changes vary across occupations. This suggests that occupations benefited differently from the new technology.

The data that include information on technology and occupation switchers are useful for three reasons. First, we can construct a subsample of technology switchers who retain their initial occupations across job-moves. Thus, we can use individual fixed effects estimation to address time-invariant worker heterogeneity and, in particular, to confirm that estimates on the impact of technology on occupational wages are not conflated with effects stemming from simultaneous occupational switching. Second, we can exploit the within-individual variation in occupations when estimating the evolution of relative wages over the sample period. This is particularly true for the old occupations on sailing vessels but also holds for engine room operators under steam technology. For engineers, our data are less numerous, the identification relying on 79 mariners who are either promoted from the position of engine room operator to the rank of engineer (51 cases), or vice versa (28 cases). Third, the transition data provide some clues for why longlasting wage premiums may have existed.

[Tables 2 - 4 around here] 


\section{The effect of technological change on the wage structure: empirical analysis}

In this section, we empirically assess the theoretical model derived in Section II. We will focus on three points. First, the polarisation hypothesis indicates that the wages of mates, $w_{a}$, should increase both absolutely (i.e., positive steam premium within mates) and relative to the wages of the able-bodied seamen, $w_{r}$, and ordinary seamen, $w_{m}$. In other words, both the absolute wage and the occupation premium of mates should be higher under the steam than the sail technology.

Second, due to the q-complementarity of routine and manual tasks on vessels, the steam engine raises the marginal productivity of manual task labour input, resulting in an increase in the wages of manual labour. A shift of additional labour from routine to manual tasks, however, works against this effect. It is, hence, possible that both $w_{m}$ and $w_{r}$ could decline despite that the manual task wage relative to the routine task wage, $w_{m} / w_{r}$, increases. Thus, the steam premium for the ordinary seamen is either negative or positive, and their occupational premium in relation to the able-bodied seamen is less negative under the steam than the sail technology.

Third, with respect to the new occupations, the model indicates that the adoption of the steam engine benefits the high-skilled abstract task labour force (engineers) and potentially also unskilled manual task labour (engine room operators). Although the model provides no guidance whether the wages of engineers (engine room operators) are higher or lower than those of mates (ordinary seamen), it predicts that the wages of engineers in relation to mates should increase over time due to the decline in the market price of steam engines.

\section{A. Absolute wage effects: results for the adopters of new technology}

In this sub-section, we provide estimates on aggregate and occupational steam premiums for occupations that existed under both technologies - mates, able-bodied 
seamen and ordinary seamen - using data on mariners who switched between the technologies during their careers. We were able to identify 1,027 mariners who switched from sail to steam, or vice versa, in the period between 1869 and $1910 .{ }^{12}$ These job-moves account for 3,271 observations in total. We restrict the sample further by considering only those job-moves where the mariner's occupation remained unchanged at the time of the switch. Thus the estimate on the impact of technology on wages is not biased by the occupational switching that may occur at the time of the move or during the subsequent career. This definition reduces the total number of observations to 2,270 and 713 different individuals.

Our estimates on the aggregate steam premium are based on the following wage equation: ${ }^{13}$

$$
\ln w_{i j t}=\mu_{i}+\beta \text { OldOCC }_{i t}+\vartheta_{1} \text { steam }_{j t}+\varsigma X_{i t}+\tau Y_{j t}+\delta Z_{i j t}+d t+\varepsilon_{i t}
$$

where the $(\log )$ monthly wage in 1914 Swedish kronor, $\ln w_{i j t}$, is regressed on individual $i$ (vector $\mathbf{X}$ ), vessel $j(\mathbf{Y})$ and contract $(\mathbf{Z})$ characteristics ${ }^{14}$. The parameter $d t$ denotes the year fixed effect ${ }^{15}, \mu_{i}$ represents the panel effect associated with individuals and $\varepsilon_{i t}$ is a random error term. The parameter OldOcc $_{i t}$ denotes dummies for the old occupations, mates, able-bodied seamen and ordinary seamen, separately. The variable steam $_{j t}$ is a dummy for a steam-powered vessel.

The full sample OLS estimates (column 1 of Table 5) without controls indicate that the aggregate technology premium is 27 per cent. The inclusion of observables, individual,

${ }^{12}$ The estimation period is 1869 to 1910 rather than 1869 to 1914 due to a limited number of observations.

${ }^{13}$ Wages and other contract characteristics on vessels were bargained over at the beginning of each voyage, and these contracts were in force during the entire voyage.

${ }^{14}$ Regressors capturing the individual, vessel and contract characteristics are: age, age squared, a dummy for marital status, registertonne and the duration of the contract.

${ }^{15}$ The year dummies are likely to capture a number of industry level effects. On the demand side, the transition towards larger vessels obviously reduces the demand for mariners. The decline in the costs of shipping was, in turn, likely to increase this demand. 
vessel and contract-specific, reduces the estimate to 8 per cent. The corresponding estimates for the sample of all technology switchers, as well as for the sample that includes only occupational switchers who retained their occupations after the switch, are of the same magnitude, at approximately 10 per cent in both cases. The specification that adds precision by controlling for time-invariant individual heterogeneity produces a comparable estimate: the aggregate steam premium enjoyed by mariners on steam vessels over those in sailing vessels is approximately 7 per cent. The estimates prompt two conclusions. First, differences in the results between the samples and estimation methods are moderate, although there seems to be a certain degree of selection among mariners who switch technologies. Overall, the result that technology switchers represent all seamen in the sample well is in line with the wage comparisons shown in Table 4. Second, the steam premium is significant, at approximately 7-10 per cent. Thus it pays to work on steamships. This result, in turn, prompts further questions: why does such a premium exists, and does it vary across occupations?

Table 6 extends the analysis by reporting estimates on steam premiums by occupation, estimated separately for the old occupations. The results imply that the aggregate steam premium estimates provide only a partial view of the impact of steam technology on wages: steam premiums vary between occupations, and unobserved individual heterogeneity plays a varying role in determining the magnitudes of these premiums. For mates, the OLS estimate is 11.6 per cent. The inclusion of individual fixed effects yields a considerable decrease in the premium, to 8.7 per cent. This decrease suggests that more productive mates obtained better-paid positions on steam vessels than their less productive counterparts, or they were employed, in general, on more productive steam vessels (Woodcock, 2008 and Abowd, Kramarz \& Margolis, 1999). For ordinary seamen, the controlling for the unobserved heterogeneity does not change the premium estimates: the estimate is 13 per cent in both cases. For the able-bodied seamen, the fixed effects estimate is statistically significant and negative ( -2.7 per cent), whereas the OLS results indicate a zero premium. In sum, both the high-skilled and unskilled groups of occupations seemed to benefit from the new technology in the form of increased absolute wages, while the wages of the intermediate-skilled group declined. This result underlines the polarising nature of the technological change. 
The aggregate steam premium can be rationalised and explained by productivity growth brought about by steam technology. However, why did the premiums vary across occupations? According to our theoretical model on wage polarisation, mates in abstract tasks $\left(L_{a}\right)$ unambiguously benefit from the steam engine due to the q-complementarity of the abstract tasks and the routine task input provided by the new technology. The qcomplementarity also holds between the manual task input $L_{m}$ and the routine task input provided by the new technology, $K$. The additional labour input from the routine tasks $L_{r}$ could, however, cancel out this positive absolute wage effect of the steam engine, but this is not the case here because the ordinary seamen also benefit from the new technology.

It is also reasonable to assume that, following Chin et al. (2006), working conditions varied across technologies and across occupations within technologies, and there were differences in practical work across steamers and sailing vessels. For mates, the command of a steamer required, to some degree, different skills and routines than commanding a sailing vessel. The new skill requirements were primarily related to the technology used but also simply to the larger size of the steamers compared to sailing vessels. In short, the work of mates was more demanding and necessitated greater responsibilities in ports and, thus, the pay was also better. The circumstances differed for able-bodied seamen. Some of their skills were likely to lose value on steamers, as the handling of ropes or rigging, for example, are less important on steamers than on sailing vessels. There was also no compensating differential because the work on board a steamer was certainly safer and less demanding than that on a sailing vessel. For example, there was no need to climb up masts during the storms. For ordinary seamen, the positive steam premium was more likely to reflect compensation in terms of working conditions rather than a skill premium. The work of ordinary seamen on steamers was in most cases rather difficult, manual work with fewer prospects of obtaining a better position through experience and learning than on sailing vessels. In some cases, an individual who had worked as an OS on a sailing vessel would likely be an engine room operator on a steamer, in other words, shovelling the coal into the engines. 
[Tables 5 and 6 about here]

\section{B. Relative occupational wage effects}

The previous analysis demonstrated that the impact of the new technology on wages varied across occupations that existed on sailing vessels. This, of course, implies that the relative wages between occupations changed over time when the industry adopted the new technology. In this sub-section, we examine how occupational wages evolved throughout the period of study in greater detail. The question is interesting because the new technology created two groups that did not exist on sailing vessels, one working on abstract tasks (engineers) and one working on manual tasks (engine room operators). Thus, the analysis enables us to empirically evaluate our theoretical framework predicting that the adoption of the steam engine should benefit high-skilled, abstract task labour, and potentially also unskilled manual task labour.

To explicate the wage differentials between occupations under sail and steam technologies and simultaneously retaining the individual information and observations from both technologies, we augmented model (3) by including the new occupations and interaction terms between the steam dummy and the dummies for the old occupations, excluding the able-bodied seamen, which is employed as a reference group.

$$
\begin{aligned}
& \ln w_{i j t}=\mu_{i}+\beta \text { OldOCC }_{i t}+\vartheta_{1} \text { steam }_{j t}+\vartheta_{2} \text { steam }_{j t} * \text { OldOCC }_{i t}+ \\
& \rho N e w O C C_{i t}+\varsigma X_{i t}+\tau Y_{j t}+\delta Z_{i j t}+d t+\varepsilon_{i t},
\end{aligned}
$$

where $N e w O c c_{i t}$ denotes dummies for new occupations that only appeared under the steam technology, that is, engineers and engine room operators, separately. Dummies for the old occupations are interacted with the steam dummy to identify the occupational premiums under both sail and steam technologies.

Table 7 reports the OLS (columns $\mathrm{i}$ and iii) and fixed effects coefficients (columns ii and iv). In the latter case, the identification of wage parameters is based on occupation switching. As shown in Table 2, such cases are numerous for the old occupations. For mates, there are 1,301 occupational moves under sail technology and 187 under steam. 
For able-bodied seamen, the corresponding numbers are 1,572 and 232 and for ordinary seamen 2,240 and 182, respectively. For the new occupations, occupational switches are less common. For engine room operators, we observe 91 occupational moves. For engineers, the figure is smaller, at only 31 (see Table 3 ).

The OLS estimates imply that mates earned approximately 22 per cent more than ablebodied seamen under sail technology. The premium decreases to 12 per cent when the time-invariant individual heterogeneity is controlled for using fixed effects. As previously demonstrated with the steam premiums, this indicates that mariners with higher innate ability were selected into the occupation of mates. The opposite holds for ordinary seamen. The negative wage premium of approximately -40 per cent relative to able-bodied seamen is reduced to -28 per cent under sail technology when we control for innate ability.

Mates clearly improved their relative position on steamboats. The average premium of 12 per cent relative to able-bodied seamen under sail technology rose to 27 per cent under steam technology. The increase matches the sum of the estimates on positive steam premium for mates (approximately 10 per cent) and negative steam premiums for able-bodied seamen (approximately 3 per cent). Ordinary seamen similarly improved their position, as the negative wage premium of -23 per cent relative to able-bodied seamen under sail technology was reduced to -12 per cent under steam technology. The increase is of the same magnitude as suggested by the steam premium for this group (approximately 13 per cent).

The occupational premiums for the new occupations further confirm the weakened position of the intermediate-skilled, able-bodied seamen under the new technology. According to the fixed effects estimates, engineers earned 59 per cent and manual task engine room operators 20 per cent more than able-bodied seamen. When comparing the specifications with and without individual fixed effects, individuals with higher innate ability were selected as engineers, while those with lower ability were selected to work as engine room operators. As Chin et al. (2006) note, premiums from working on steam vessels include a compensating differential for the unpleasant work environment and for skills gained from training. The former applies to engine room operators, who worked 
under poor conditions below decks. ${ }^{16}$ The skill argument suits the engineers. The size of their skill premium was also likely to reflect their relative supply. There was a shortage of qualified engineers due to increasing work opportunities on land, brought about by the industrialisation of the Swedish economy from the mid-1800 onwards.

Figure 5 depicts the time paths of the estimated wage premiums by occupation during the period between 1874 and 1910. The reference group is able-bodied seamen. The premium enjoyed by mates remains at a higher level under steam technology than under sail technology, and the premium enjoyed by ordinary seamen is less negative under steam technology, as previously suggested by the occupational steam premium estimates. Engineers improve their relative wage position throughout the early adaption period to the year 1894, and then remain stable. Similarly engine room operatives continuously improve their relative position over the early adaptation phase. From 1894 onwards, their position begins to weaken.

In summary, the results for the steam and occupational premiums are consistent with the theory that the new technology has a polarising effect on the labour market. The adoption of the new technology in the merchant marine increased the wages of abstract task high-skilled labour and the wages of manual task unskilled labour, both absolutely and relative to intermediate-skilled routine task labourer. The routine task labourer, in turn, suffered both absolutely and in relation to the other groups. The relative wage of the new occupations increased substantially over the adoption phase of the new technology, reflecting an increase in demand for their skills and their labour input.

Can we claim that this change in the wage structure of the maritime industry was due to steam? Or was it due to changes in the aggregate wage structure occurring simultaneously in the Swedish labour market? The latter possibility cannot be ignored, as the maritime industry accounted for only a small share of the Swedish economy and, therefore, was a price-taker in the labour market. We cannot offer definite answers to these questions. However, one can ask the question that if there was a similar change in the Swedish labour market after the mid-1800s to the one that occurred in the maritime

\footnotetext{
${ }^{16}$ See Sager (1993), Griffiths (1997) and Kaukiainen (1991) for description of work in engine rooms.
} 
industry, what caused such a change in the aggregate wage structure? One obvious answer is, again, the steam technology that gave rise to the industrialisation of the Swedish economy from the mid-1800. As Sjögren (2008) states, the mid-nineteenth century in Sweden was characterised by liberal reforms, railways, export trade and mechanisations associated with industrialisation and rapid economic growth. Steam engines and water turbines were the key technologies in Swedish industrialisation in this era. Thus, there was a clear knowledge accumulation and transfer of steam technology within society at the time of transition from sail to steam in shipping.

[Table 7 and Figure 5 about here] 


\section{Conclusions}

This study unravels the evolution of the absolute and relative wages received by the labour force using linked employer-employee panel data from the maritime industry between 1869 and 1914. A major shift in production technology from sail-only vessels to steam-operated vessels allowed us to examine the impact of a technological change on the relative position of labourers endowed with different skills in a well-defined setting.

According to the analysis, the technological change substantially restructured the occupational composition of the maritime industry. The adoption of the steam engine not only changed the capital intensity, but it also created new occupations. Our study suggests that technology switchers from sail to steam typically move into occupations that existed in sail. Cases where a mariner simultaneously switches technologies from sail to steam and an old sailing occupation to a new steam occupation are rare. Similarly, switches from steam to sail are uncommon. These findings indicate that the labour markets for the two technologies are segregated, and labourers in new occupations on steamships were entrants to the industry.

Steam technology had a new-skill-demanding aspect that emerged as an increase in the demand for high-skilled engineers. This is consistent with views (e.g., Brenner et al. 1991) that early technological progress was unbalanced in favour of capital/skill intensive sectors, as it shifted relative factor demands away from unskilled labour. Steam technology also had a skill-replacing aspect, which resulted in a decrease in the demand for intermediate-skilled, able-bodied seamen and an increase in the demand for unskilled engine room operators. This finding is, in turn, consistent with studies (e.g., Habakkuk 1962, James and Skinner 1985) demonstrating that early industrialisation was biased towards unskilled workers, which was shown, for example, by an increase in the number of women and children in the labour force.

The effect of the new steam technology on the wage structure of the maritime industry was marked. Our findings, which are based on historical data, are compatible with the hypothesis of technology-based polarisation, a view that has gained increased support 
from analyses of contemporary data, including those of Autor et al. (2006), Goos and Manning (2007), Goos et al. (2009) Van Reenen (2011). In summary, we found that the high-skilled labour force working in abstract task occupations and the unskilled labour force working in manual task occupations improved their positions in absolute terms (a positive steam premium within occupations) and relative to the intermediate-skilled labour force working in routine task occupations (increased wages under the steam technology relative to the intermediate-skilled). The appearance of the new occupations in conjunction with the steam engine further strengthens the wage polarisation by job task. 


\section{References}

Abowd, John M., Francis Kramarz, and David N. Margolis. 1999. High wage workers and high wage firms. Econometrica 67:251-333.

Acemoglu, Daron. 2002. Technical change, inequality and the labor market. Journal of Economic Literature 40:7-72.

Atack, Jeremy, Fred Bateman, and Robert A. Margo. 2004. Skill intensity and rising wage dispersion in nineteenth-century American manufacturing. Journal of Economic History 64:172-192.

Autor, David, and David Dorn. 2012. The growth of low-skill service jobs and the polarization of the U.S. labor market. MIT Working Paper.

Autor, David, Lawrence Katz, and Melissa S. Kearney. 2006. Polarization of the U.S. labor market. American Economic Review 96, no. 2:189-194.

Autor, David, Lawrence Katz, and Melissa S. Kearney. 2008. Trends in U.S wage inequality: revising the revisionists. Review of Economics and Statistics 90, no. $2: 300-323$.

Autor, David, Frank Levy, and Richard D. Murnane. 2003. The skill content of recent technological change: an empirical exploration. Quarterly Journal of Economics 118:1279-1333.

Berman, Eli, John Bound, and Stephen Machin. 1998. Implications of skill-biased technological change: international evidence. Quarterly Journal of Economics 113:1245-1280.

Bound, John, and George Johnson. 1992. Changes in the structure of wages in the 1980s: an evaluation of alternative explanations. American Economic Review 83:371-392.

Brenner, Y.S., Hartmut Kaelble, and Mark Thomas. 1991. Income Distribution in Historical Perspective (eds.). Cambridge University Press. 
Card, David, and John E. DiNardo. 2002. Skill-biased technological change and rising wage inequality: some problems and puzzles. Journal of Labor Economics 20:733783.

Chin, Aimee, Chinhui Juhn, and Peter Thompson. 2006. Technical change and the demand for skills during the second industrial revolution: evidence from the merchant marine, 1865-1912. Review of Economics and Statistics 88, no. 3:572-578.

Dunne, Timothy, Lucia Foster, John Haltiwanger, and Kenneth R. Troske. 2004. Wage and productivity dispersion in the United States manufacturing: the role of computer investment. Journal of Labor Economics 22, no. 2:397-429.

Dunne, Timothy, John Haltiwanger, and Kenneth R. Troske. 1997. Technology and jobs: secular changes and cyclical dynamics. Carnegie-Rochester Conference Series on Public Policy 46:107-178.

Fischer, Lewis R. 1979. The Great Mudhole Fleet: The voyages and productivity of the sailing vessels of Saint John, 1863-1912. In David Alexander and Rosemary Ommer (eds.), Volumes not Values: Canadian Sailing Ships and World Trades. St. Johns', Maritime History Group.

Fritz, Martin. 1980. Shipping in Sweden, 1850 - 1913. The Scandinavian Economic History Review 28, no. 2: 147 - 160.

Gjolberg, Ole. 1980. The substitution of steam for sail in Norwegian ocean shipping, 1866 - 1914. A Study in the Economics of Diffusion. The Scandinavian Economic History Review 28, no. 2: 135 - 146.

Goldin, Claudia, and Lawrence F. Katz. 2008. The race between education and technology: the evolution of U.S. educational wage differentials, 1890-2005. The Race between Education and Technology, Harvard University Press.

Goldin, Claudia, and Lawrence F. Katz. 1998. The origins of technology-skill complementarity. Quarterly Journal of Economics 113(3), 693-732.

Goos, Maarten, and Alan Manning. 2007. Lousy and lovely jobs: the rising polarization of work in Britain. Review of Economics and Statistics 89, no. 1:118-133. 
Goos, Maarten, Alan Manning, and Anne Salomons. 2009. Job polarization in Europe. American Economic Review Papers and Proceedings 99, no. 2:58-63.

Graham, G. S. 1956. Ascendancy of the sailing ships 1850-85."Economic History Review 9, no. 1: 74-88

Griffiths, Denis. 1997. Steam at Sea. London: Conway Maritime Press.

Habakkuk, John. 1962. American and British technology in the nineteenth century: the search for labor-saving inventions. Cambridge University Press.

Harley, C. K.1971. The shift from sailing ships to steamships 1850-1890: A study in technological change and its diffusion. In Donald N. McCloskey (ed), Essays on a Mature Economy: Britain after 1840. Princeton, New Jersey, Methuen \& Co. Ltd.: 215-231.

Harley, C. K. 1988. Ocean freight rates and productivity, 1740-1913: The primacy of mechanical invention reaffirmed. Journal of Economic History 48, no. 4: 851-876.

Hornby, Ove, and Carl-Axel Nilsson. 1980. The transition from sail to steam in the Danish merchant fleet. The Scandinavian Economic History Review 28, no. 2: 109 134.

Isserliss, L. (1938). Tramp Shipping Cargoes, and Freights. Journal of the Royal Statistical Society 101: 53-I46.

James, John A., and Jonathan S. Skinner. 1985. The resolution of the labour-scarcity paradox. The Journal of Economic History 45, no. 3: 513-540.

Juhn, Chinhui. 1999. Wage inequality and demand for skill: evidence from five decades. Industrial and Labour Relations Review 52, no. 3: 424-443.

Katz, Lawrence, and David Autor. 1999. Changes in the wage structure and earnings inequality. Ashenfelter, Orley, and David Card (eds.): Handbook of Labour Economics, Volume 3A, Amsterdam: Elsevier.

Katz, Lawrence, and Kevin M. Murphy. 1992. Changes in relative wages, 1963-1987: supply and demand factors. Quarterly Journal of Economics 108:1035-78. 
Kaukiainen, Yrjö. 1991. Sailing into Twilight. Finnish Shipping in an Age of Transport Revolution, 1860-1914. Helsinki, Suomen Historiallinen Seura.

Lemieux, Thomas. 2006. Increased residual wage inequality: compositional effects, noisy data, or rising demand for skill. American Economic Review 96, no. 2:461-498.

Machin, Stephen, and John Van Reenen. 1998. Technology and changes in skill structure: evidence from seven OECD countries. Quarterly Journal of Economics 113:1215-1244.

Mitchell, Mathew F. 2005. Specialization and the skill premium in the $20^{\text {th }}$ century. International Economic Review 46, no. 3: 935-955.

North, Douglass C. 1958. Ocean freight rates and economic development 1750-1913. Journal of Economic History 18, no. 4: 537-555.

North, Douglass C. 1968. Sources of productivity changes in ocean shipping 16001850. Journal of Political Economy 76, no. 5: 953-970.

Ojala, Jari, and Jaakko Pehkonen. 2009. Technological changes, wage inequality and skill premiums: evidence over three centuries. Working Papers No. 5, Government Institute for Economic Research. Helsinki.

Unger, Richard W. 2011. Shipping and Economic Growth 1350-1850. Global Economic History Series. Volume 7. Leiden-Boston: Brill.

Sager, Eric W. 1989. Seafaring Labour. Montreal: McGill-Queens's University Press.

Sjögren, Hans. 2008. Welfare Capitalisms: the Swedish Economy, 1850-2005. In S. Fellman, M. Iversen, H. Sjögren \& L. Thue (Eds.), Creating Nordic Capitalism. The Development of a Competitive Periphery. Basingstoke: Palgrave Macmillan

Van Reenen, John. 2011. Wage inequality, technology and trade: $21^{\text {st }}$ century evidence. Labour Economics 18:730-741.

Woodcock, Simon D. 2008. Wage differentials in the presence of unobserved worker, firm, and match heterogeneity. Labour Economics 15:772-794. 


\section{Figures and tables}

Fig. 1 Technological change in the maritime industry: the proportion of workers on steam vessels, five-year averages over 1869-1914

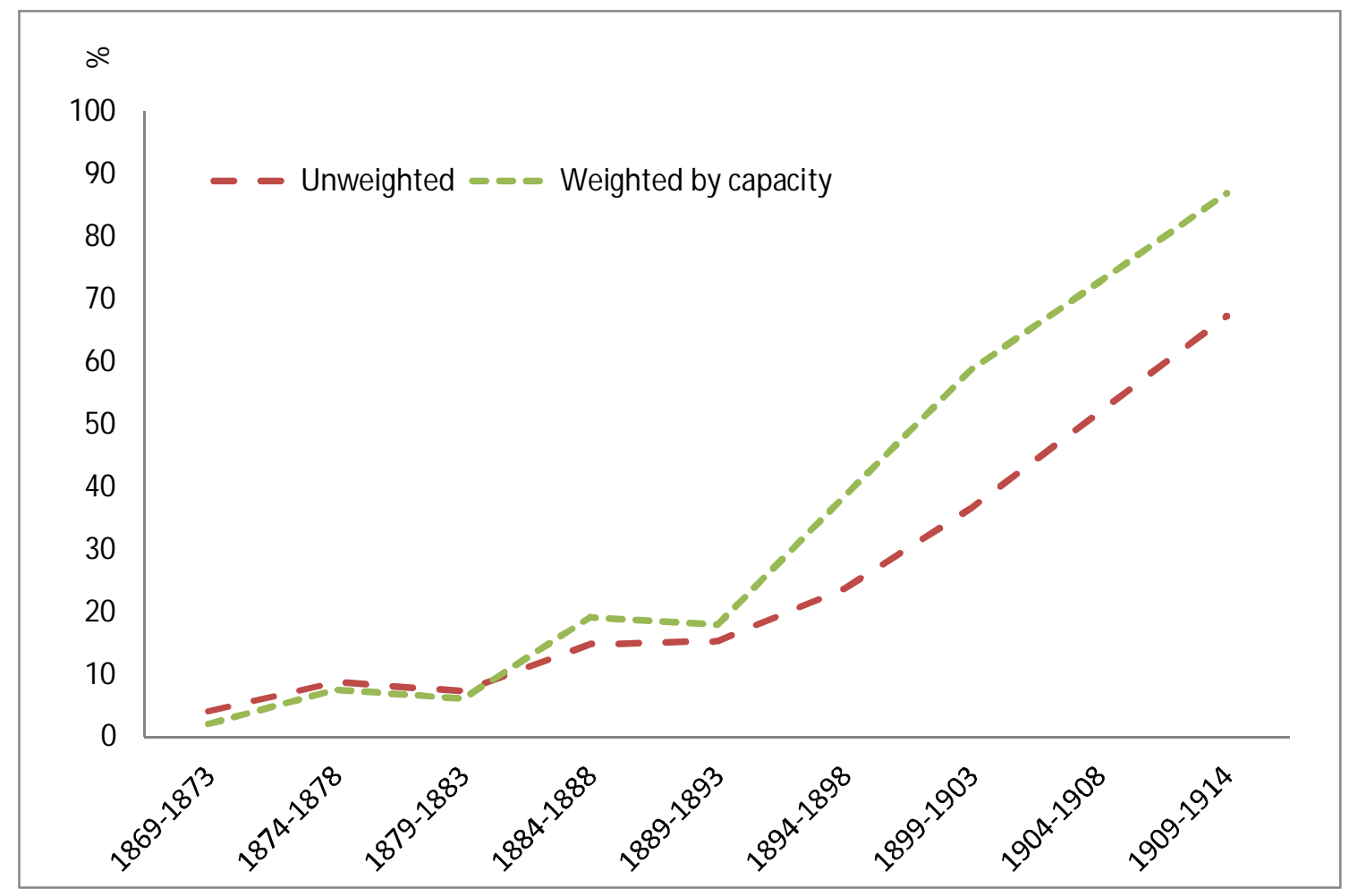


Fig. 2 Crew composition, all vessels, five-year averages over 1869-1914

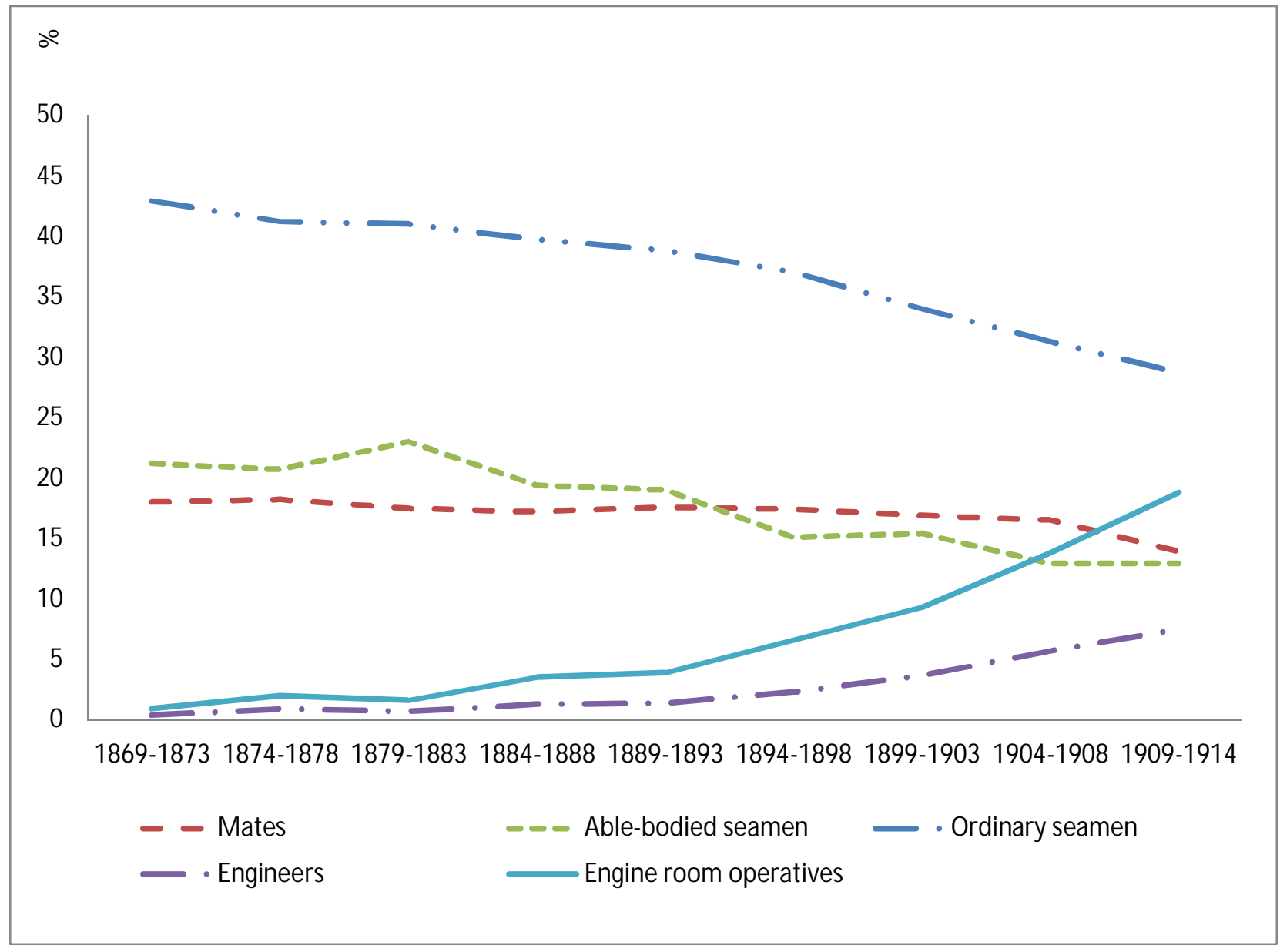


Fig. 3 Wages by occupation, five-year averages over 1869-1914

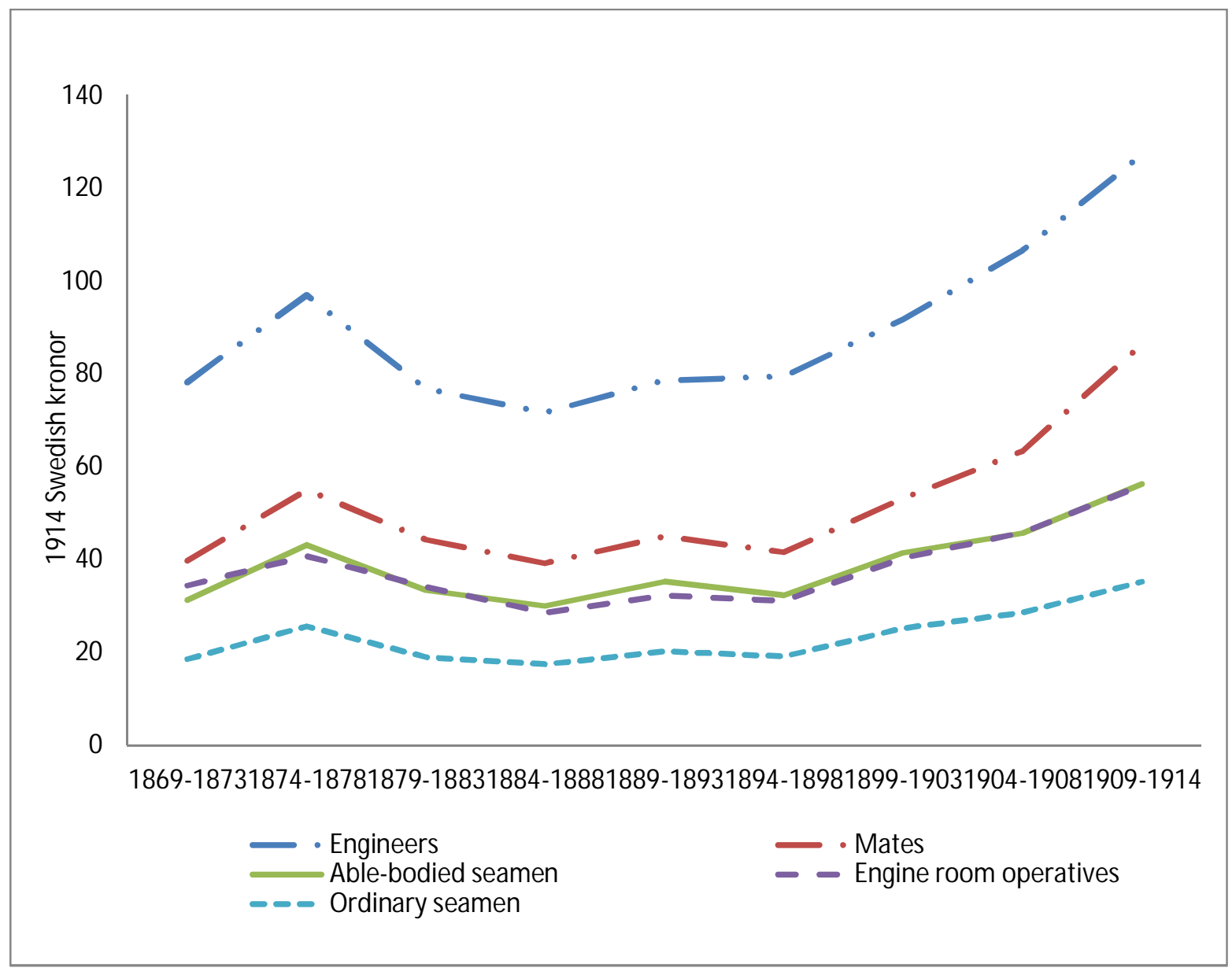


Fig. 4 Average wage growth (\%) by deciles in the periods 1869-1890 and 1890-1914

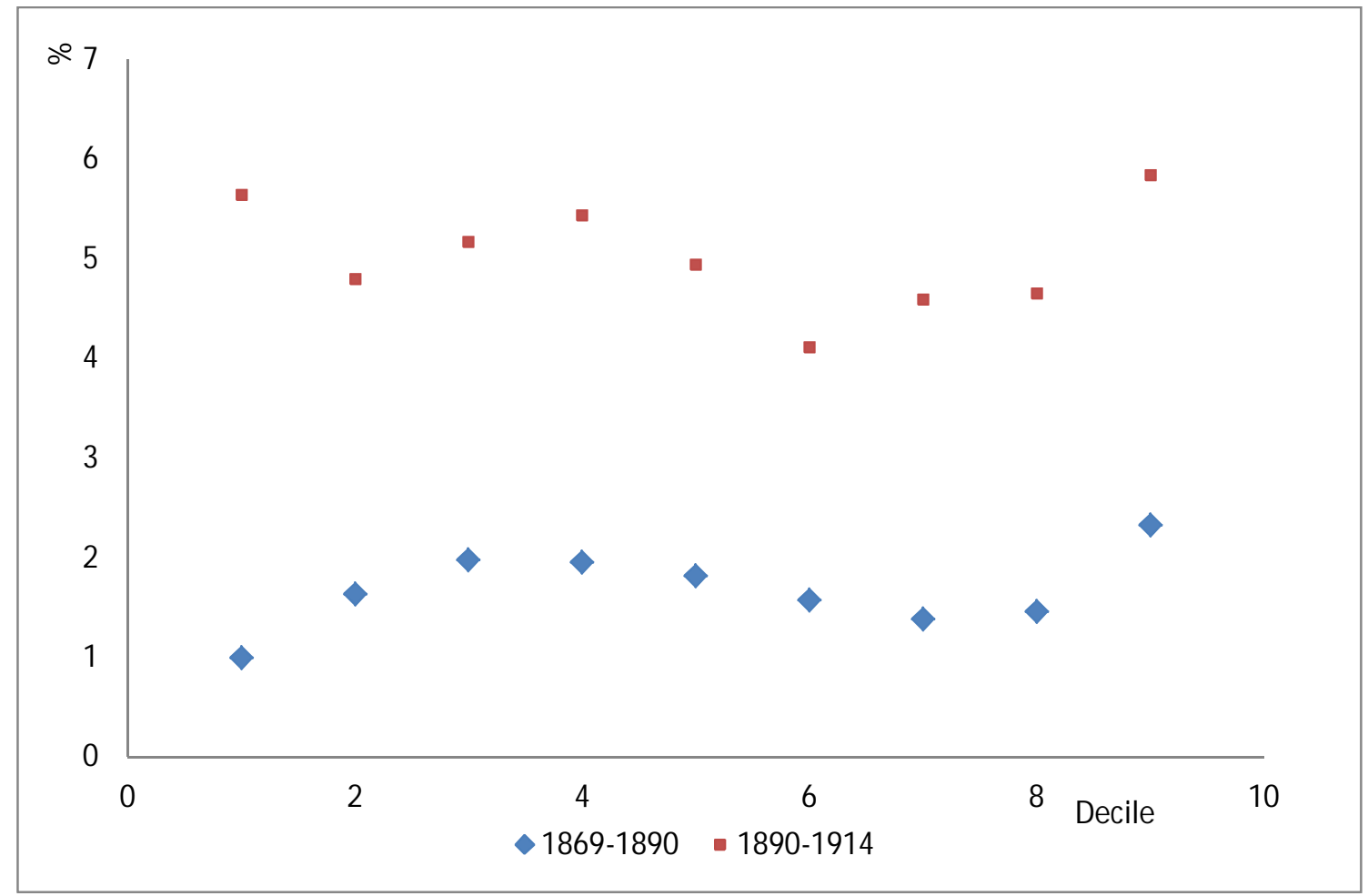


Fig. 5 Evolution of occupational premiums under sail and steam technologies in the 1869-1910 period, 10-year moving averages

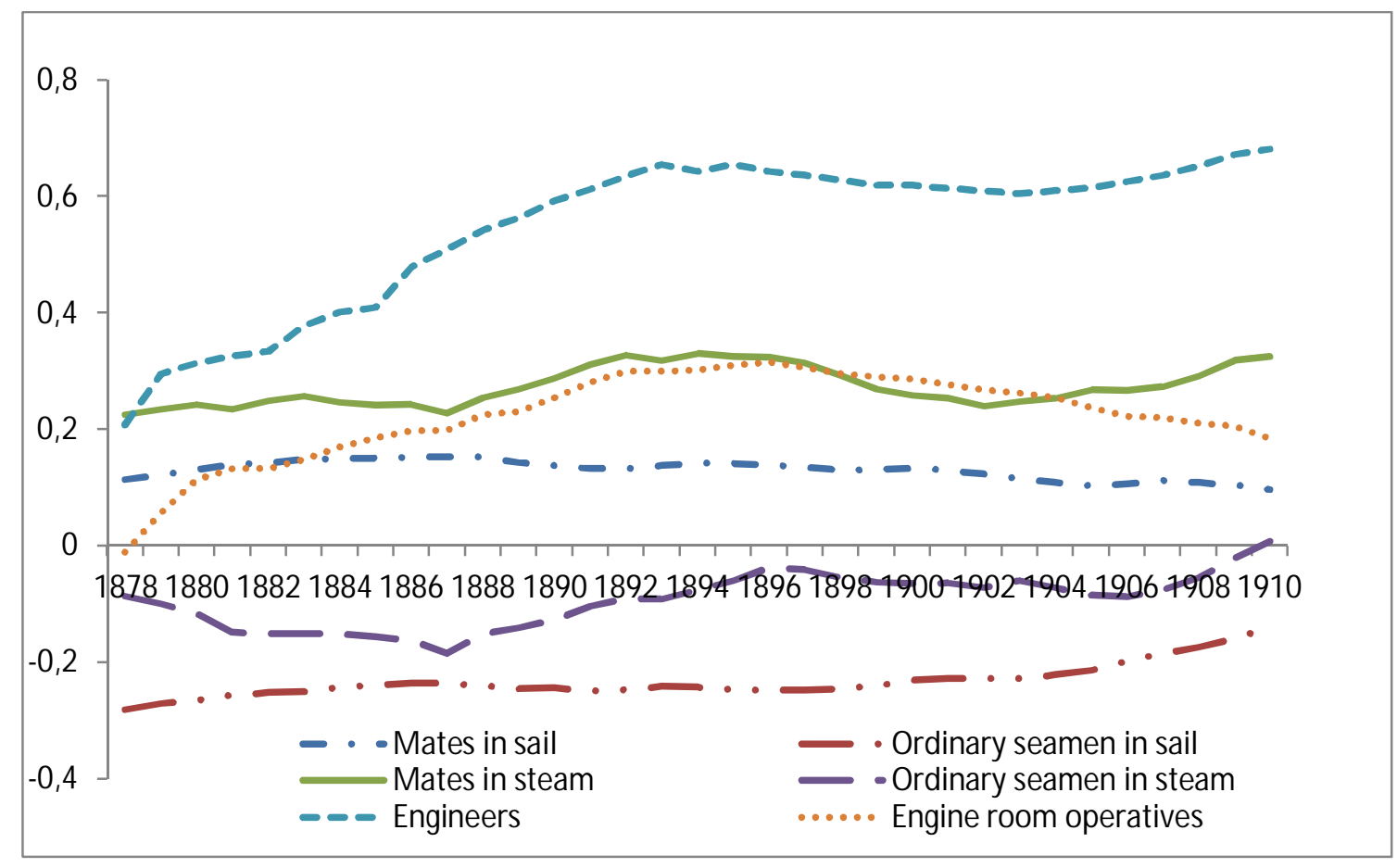

The premiums for engineers, engine room operators, mates and ordinary seamen under steam technology were estimated relative to able-bodied seamen employed under steam technology. Premiums for mates and ordinary seamen under sail technology were estimated relative to able-bodied seamen under sail technology. Estimates are based on specification (4), augmented by a full set of occupation-year-steam-vessel interactions. 
Table 1 Employment and wage bill shares by occupation, 1869-1914

\begin{tabular}{|lcc|}
\hline & Employment share & Wage bill share \\
\hline Sail technology & & \\
Mates & 18.9 & 28.1 \\
Able-bodied seamen & 18.5 & 21.4 \\
Ordinary seamen & 41.7 & 28.7 \\
Others & 20.9 & 21.8 \\
& & \\
Steam technology & & \\
Mates & 11.0 & 15.4 \\
Able-bodied seamen & 17.5 & 13.5 \\
Ordinary seamen & 23.9 & 12.5 \\
Engineers & 10.7 & 19.7 \\
Engine room operatives & 27.1 & 21.4 \\
Others & 9.8 & 17.5 \\
\hline
\end{tabular}

The occupation category 'Others' includes captains, stewards, cooks and deck-boys. Wages are monthly wages on voyages in 1914 Swedish kronor. 
Table 2 Job-moves within sail technology (columns i-iii) and across technologies (columns iv-viii), \%-shares of all job-moves

\begin{tabular}{|c|c|c|c|c|c|c|c|c|c|}
\hline & & Sail(t) & & & & eam( & & & \\
\hline & & (i) & (ii) & (iii) & (iv) & (v) & (vi) & (vii) & (viii) \\
\hline & & Mate & $A B$ & OS & Mate & $A B$ & OS & ENG & ERO \\
\hline & Mate & 0.62 & 0.20 & 0.17 & 0.56 & 0.35 & 0.09 & 0.00 & 0.00 \\
\hline Sail(t-1) & $A B$ & 0.19 & 0.60 & 0.20 & 0.17 & 0.70 & 0.10 & 0.004 & 0.02 \\
\hline & OS & 0.13 & 0.18 & 0.69 & 0.22 & 0.36 & 0.37 & 0.002 & 0.04 \\
\hline
\end{tabular}

Total number of job-moves from sail to sail (steam) is 13,239 (987), consisting of 3,188 (224) mates, 3,807 (224) able-bodied seamen, and 6,244 (539) ordinary seamen. The job-move is identified using two successive labour contracts for a seaman. 
Table 3 Job-moves within steam technology (columns i-v) and across technologies (columns vi-viii), \%-shares of all job-moves

\begin{tabular}{|c|c|c|c|c|c|c|c|c|c|}
\hline & & \multicolumn{5}{|c|}{$\operatorname{Steam}(t)$} & \multicolumn{3}{|c|}{ Sail(t) } \\
\hline \multirow{7}{*}{ Steam $(\mathrm{t}-1)$} & & (i) & (ii) & (iii) & (iv) & (v) & (vi) & (vii) & (viii) \\
\hline & & Mate & $\mathrm{AB}$ & OS & ENG & EOR & Mate & $\mathrm{AB}$ & OS \\
\hline & Mate & 0.90 & 0.06 & 0.03 & 0.00 & 0.01 & 0.50 & 0.13 & 0.37 \\
\hline & $\mathrm{AB}$ & 0.05 & 0.88 & 0.06 & 0.00 & 0.01 & 0.24 & 0.40 & 0.36 \\
\hline & OS & 0.03 & 0.13 & 0.78 & 0.00 & 0.06 & 0.13 & 0.16 & 0.71 \\
\hline & ENG & 0.00 & 0.00 & 0.00 & 0.88 & 0.12 & 0.00 & 0.50 & 0.50 \\
\hline & EOR & 0.00 & 0.01 & 0.02 & 0.10 & 0.87 & 0.00 & 0.29 & 0.71 \\
\hline
\end{tabular}

Total number of job-moves from steam to steam (sail) is 2.232 (1102), consisting of 325 (316) mates, 584 (433) able-bodied seamen, 568 (330) ordinary seamen, 230 (2) engineers, and 525 (21) engine room operators. The job-move is identified using two successive labour contracts for a seaman. 
Table 4 Comparison of the wages of technology switchers to average wages, periods $1869-90$ and 1890-1910

\begin{tabular}{|c|c|c|c|c|c|c|}
\hline & \multicolumn{3}{|c|}{ Wages in sail } & \multicolumn{2}{|l|}{ Wages in steam } & \multirow[b]{2}{*}{$\begin{array}{c}\text { Switcher } \\
\text { from } \\
\text { steam }\end{array}$} \\
\hline Mates & All & & $\begin{array}{l}\text { Switchers } \\
\text { from sail }\end{array}$ & All & & \\
\hline $1869-1890$ & $\begin{array}{c}43.7 \\
(12.2)\end{array}$ & $<$ & $\begin{array}{c}46.8 \\
(12.8)\end{array}$ & $\begin{array}{c}59.8 \\
(15.9)\end{array}$ & $\approx$ & $\begin{array}{c}59.6 \\
(15.0)\end{array}$ \\
\hline $1890-1910$ & $\begin{array}{c}45.9 \\
(11.8)\end{array}$ & $<$ & $\begin{array}{c}49.9 \\
(12.3)\end{array}$ & $\begin{array}{c}69.9 \\
(20.6)\end{array}$ & $>$ & $\begin{array}{c}67.7 \\
(20.9)\end{array}$ \\
\hline $\mathrm{AB}$ & & & & & & \\
\hline $1869-1890$ & $\begin{array}{l}34.4 \\
(9.0)\end{array}$ & $<$ & $\begin{array}{l}36.3 \\
(9.0)\end{array}$ & $\begin{array}{l}31.8 \\
(7.9)\end{array}$ & $<$ & $\begin{array}{l}33.0 \\
(8.1)\end{array}$ \\
\hline $1890-1910$ & $\begin{array}{l}36.6 \\
(8.2)\end{array}$ & $<$ & $\begin{array}{l}38.4 \\
(7.6)\end{array}$ & $\begin{array}{l}40.6 \\
(8.8)\end{array}$ & $\approx$ & $\begin{array}{l}40.4 \\
(8.2)\end{array}$ \\
\hline OS & & & & & & \\
\hline $1869-1890$ & $\begin{array}{l}19.8 \\
(7.3)\end{array}$ & $<$ & $\begin{array}{l}21.3 \\
(7.3)\end{array}$ & $\begin{array}{l}22.1 \\
(6.7)\end{array}$ & $\approx$ & $\begin{array}{l}22.6 \\
(6.7)\end{array}$ \\
\hline $1890-1910$ & $\begin{array}{l}22.1 \\
(7.4) \\
\end{array}$ & $<$ & $\begin{array}{l}23.8 \\
(7.9) \\
\end{array}$ & $\begin{array}{l}26.6 \\
(7.8) \\
\end{array}$ & $\approx$ & $\begin{array}{l}27.0 \\
(7.7) \\
\end{array}$ \\
\hline
\end{tabular}


Table 5 Estimates on aggregate steam premiums, evidence for full sample and technology switchers, 1869-1914

\begin{tabular}{l|lllll}
\hline & $\begin{array}{c}\text { Full sample. } \\
(\mathrm{i})\end{array}$ & $\begin{array}{c}\text { Full sample. } \\
(\mathrm{ii})\end{array}$ & $\begin{array}{c}\text { Switchers only } \\
\text { (iii) }\end{array}$ & $\begin{array}{c}\text { Switchers. } \\
\text { same occ.(iv) }\end{array}$ & $\begin{array}{c}\text { Switchers. } \\
\text { same occ. }(v)\end{array}$ \\
\hline $\begin{array}{l}\text { Steam } \\
\text { premium }\end{array}$ & $\begin{array}{l}0.275^{* * *} \\
(0.008)\end{array}$ & $\begin{array}{l}0.080^{* * *} \\
(0.004)\end{array}$ & $\begin{array}{l}0.106^{* * *} \\
(0.010)\end{array}$ & $\begin{array}{l}0.109^{* * *} \\
(0.011)\end{array}$ & $\begin{array}{l}0.073^{* * *} \\
(0.0010)\end{array}$ \\
$\begin{array}{l}\text { Controls } \\
\text { Fixed effects }\end{array}$ & No & Yes & Yes & Yes & Yes \\
R2 & No & No & No & Yes \\
$\begin{array}{l}\text { Number of } \\
\text { observations }\end{array}$ & 58,600 & 58,600 & 3,271 & 2,270 & 2,270 \\
$\begin{array}{l}\text { Number } \\
\text { individuals }\end{array}$ & 32,480 & 32,480 & 1,027 & 713 & 713 \\
\hline
\end{tabular}

The dependent variable is $\log \left(W_{i j t}\right)$. It is measured as an individual wage per month on a voyage that began in year $t$ measured in 1914 Swedish kronor. Control variables are age, age squared, a dummy for marital status, $\log$ (registertonne) of the vessel, the duration of the contract and yearly dummies. Standard errors are clustered by individuals and reported in parentheses. $* * *$ denotes statistical significance at the 1 per cent level. 
Table 6 Steam premiums by occupation, evidence for technology switchers who retain their occupations, 1869-1910

\begin{tabular}{|c|c|c|c|c|c|c|}
\hline & Mates (i) & Mates (ii) & $\begin{array}{l}\text { Able-bodied } \\
\text { (iii) }\end{array}$ & $\begin{array}{l}\text { Able-bodied } \\
\text { (iv) }\end{array}$ & $\begin{array}{c}\text { Ordinary } \\
\text { seamen (v) }\end{array}$ & $\begin{array}{c}\text { Ordinary } \\
\text { seamen } \\
(v i)\end{array}$ \\
\hline $\begin{array}{l}\text { Steam } \\
\text { premium }\end{array}$ & $\begin{array}{l}0.116 * * * \\
(0.020)\end{array}$ & $\begin{array}{l}0.087 * * * \\
(0.016)\end{array}$ & $\begin{array}{l}-0.013 \\
(0.015)\end{array}$ & $\begin{array}{l}-0.027^{*} \\
(0.013)\end{array}$ & $\begin{array}{l}0.131 * * * \\
(0.016)\end{array}$ & $\begin{array}{l}0.134 * * * \\
(0.014)\end{array}$ \\
\hline Fixed effects & No & Yes & No & Yes & No & Yes \\
\hline R2 & 0.60 & 0.69 & 0.64 & 0.74 & 0.56 & 0.63 \\
\hline $\begin{array}{l}\text { Number of } \\
\text { observations }\end{array}$ & 639 & 639 & 559 & 559 & 851 & 851 \\
\hline $\begin{array}{l}\text { Number of } \\
\text { individuals }\end{array}$ & 192 & 192 & 199 & 199 & 338 & 338 \\
\hline
\end{tabular}

All specifications include individual, vessel and contract controls, see Table 5. 
Table 7 Estimates on occupational premiums under sail and steam technologies, results from the OLS and FE specifications, 1869-1910

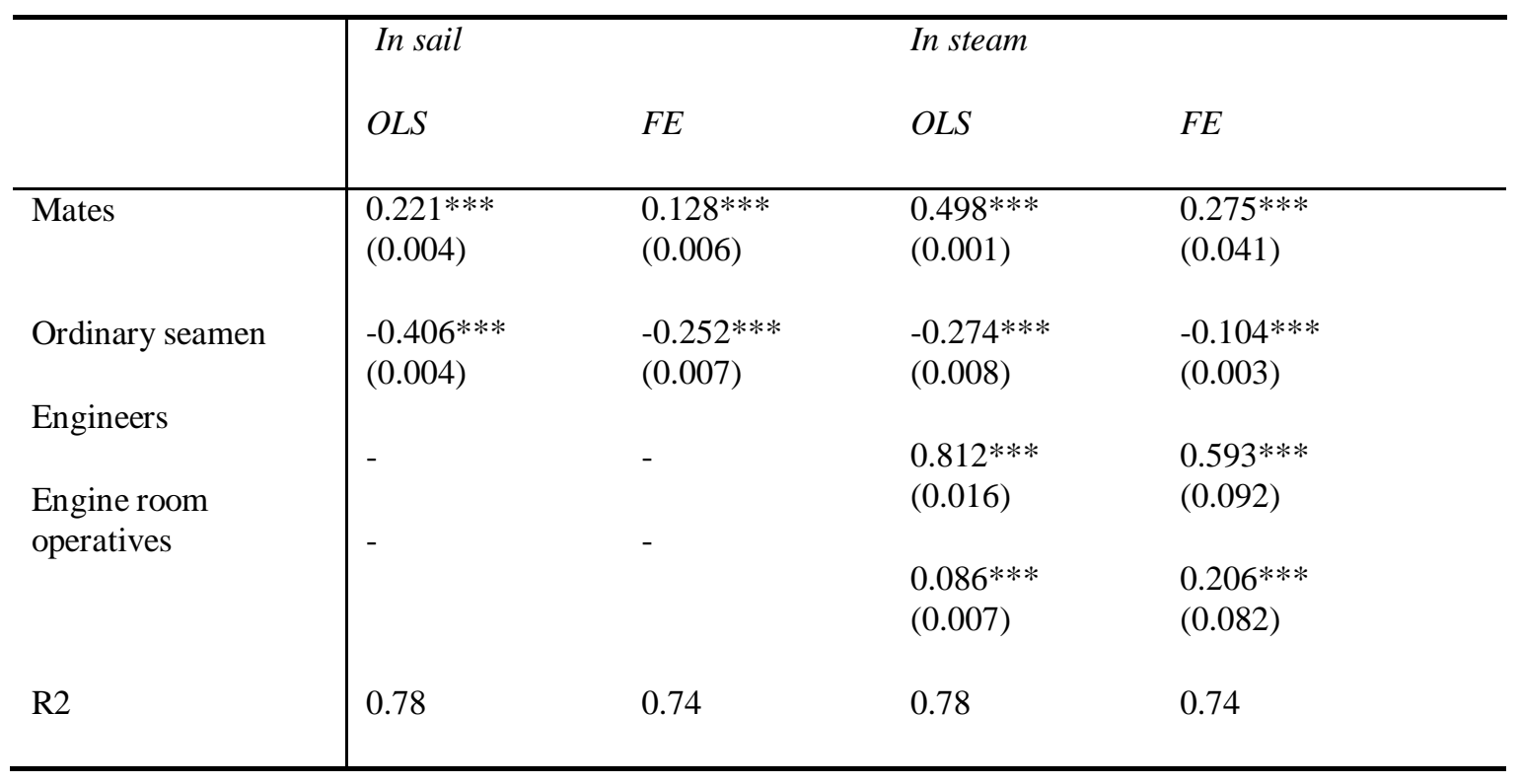

In sail (steam) the number of observations is $47,772(10,877)$, and the number of individuals is 25,529 (7,997). All specifications include individual, vessel and contract controls, see Table 5. 
